\title{
Comparison of DNA flow cytometry from fresh and paraffin embedded samples of non-Hodgkin's lymphoma
}

\author{
RS CAMPLEJOHN, JC MACARTNEY*
}

From the Richard Dimbleby Department of Cancer Research, Rayne Institute, and the Department of Histopathology, St Thomas's Hospital Medical School, London

SUMMARY Cell suspensions were prepared from fresh and paraffin embedded samples of lymph $\dot{\omega}_{\infty}^{\dot{\infty}}$ nodes from nine patients with non-Hodgkin's lymphoma. DNA flow cytometry was performed on $\vec{\circ}$ these samples and the results from fresh tissue compared with those from paraffin embedded material. Results were compared in terms of DNA index (as a measure of aneuploidy) and S phase fraction (as an indication of proliferative activity). Good agreement was found between the 0 results from the samples prepared by the two methods. The quality of DNA flow cytometry from paraffin embedded material was comparable with or better than that from fresh samples.

DNA flow cytometry is a technique that allows the recognition of cells with abnormal deoxyribonucleic acid (DNA) contents (aneuploid cells) within a population. This method also gives an indication of the proliferative activity of the cell population by allowing the estimation of the fraction of cells synthesising DNA (S phase fraction). In many types of tumour these two variables have been found to correlate with the histological grade of the tumour and to be useful prognostic indicators. In some cases they may also give information about the probable response to particular types of treatment ${ }^{12}$ : in non-Hodgkin's lymphoma a correlation has been shown between increasing histological grade and either the presence of aneuploid cells or a high fraction of proliferative cells. ${ }^{2-5}$

These studies of flow cytometry were performed on cells obtained from fresh tissue samples. Obtaining samples of fresh tissue can present practical and logistic problems and may sometimes conflict with the demands of routine pathology. Recently, a method was described that enables DNA flow cytometry to be performed on cells obtained from archival paraffin embedded blocks. ${ }^{6}$ The method allows histological samples taken over past years to be analysed retrospectively. This is a distinct advantage if, for example, rare types of tumour are being studied or if changes in DNA content during clinical progression of a tumour are being sought. The aims of the work described in this paper were to check the quality of results obtained for non-Hodgkin's lym-

Accepted for publication 6 June 1985 phoma by this method and to compare the DNA indices (a guide to the presence of aneuploid cells) $\vec{\bullet}$ and $S$ phase fractions calculated from fresh and $\infty$ paraffin embedded material. We performed ths work before undertaking detailed studies of certaim aspects of non-Hodgkin's lymphoma such as the changes that may occur in DNA content of tumour cells with clinical progression of disease.

\section{Material and methods}

DNA flow cytometry was performed on cell suspensions from both fresh tissue and paraffin blocks in nine cases of non-Hodgkin's lymphoma. In all cases cells were prepared from samples of the same lymph :node for each type of analysis. Kiel terminology was 3 used to classify the non-Hodgkin's lymphoma.

\section{PREPARATION OF CELL SUSPENSION FROM}

\section{FRESH TISSUE}

A slice of tissue, usually several millimetres thick, from the lymph node was pressed through a metal sieve with 17 grid spacings per $\mathrm{cm}$. The disaggre- $\sigma$ gated tissue was rinsed from the sieve with $5 \mathrm{ml}$ of $\mathrm{N}$ minimum essential medium, and a single cell sus- N pension was obtained by passing it through progres- $O$ sively smaller gauge needles $(21,23$, and 25$)$. This suspension was filtered through nylon gauze with a

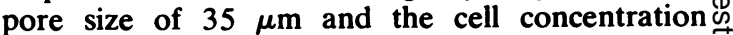
adjusted to about $10^{\circ}$ cells $/ \mathrm{ml}$. Chicken red blood cells $\left(10^{5}\right)$ were added as an internal DNA standard, and the cells were stained with DAPI $\left(4^{\prime}, \overrightarrow{\mathbb{D}}\right.$ 6-diamidino-2-phenylindol-dihydrochloride; Boeh- $\frac{\mathrm{d}}{\mathrm{D}}$ 
Table $1 S$-phase fractions calculated for fresh and paraffin embedded samples of non-Hodgkin's lymphoma

\begin{tabular}{|c|c|c|c|c|}
\hline \multirow[t]{2}{*}{ Case No } & \multirow[t]{2}{*}{ Diagnosis } & \multicolumn{3}{|c|}{$S$ phase fraction (\%) } \\
\hline & & Fresh & Fixed & Fixed and needled \\
\hline 1 & $\begin{array}{l}\text { Low grade malignant lymphoma/chronic } \\
\text { lymphocytic leukaemia }\end{array}$ & 0.9 & $2 \cdot 0$ & $1 \cdot 2$ \\
\hline $\begin{array}{l}2 \\
3 \\
4 \\
5 \\
6 \\
7 \\
8 \\
9\end{array}$ & $\begin{array}{l}\text { Low grade centroblastic-centrocytic } \\
\text { Low grade centroblastic-centrocytic } \\
\text { Peripheral T cell } \\
\text { Low grade centroblastic-centrocytic } \\
\text { T cell, polymorphic } \\
\text { High grade lymphoblastic } \\
\text { High grade centroblastic } \\
\text { High grade centroblastic }\end{array}$ & $\begin{array}{r}1 \cdot 9 \\
3 \cdot 5 \\
3 \cdot 6 \\
7 \cdot 4 \\
9 \cdot 7 \\
10 \cdot 6 \\
14 \cdot 7 \\
18 \cdot 1\end{array}$ & $\begin{array}{r}4 \cdot 0 \\
5 \cdot 9 \\
4 \cdot 9 \\
6 \cdot 3 \\
16 \cdot 0 \\
10 \cdot 0 \\
20.7 \\
24 \cdot 2\end{array}$ & $\begin{array}{r}3 \cdot 0 \\
2 \cdot 5 \\
3 \cdot 0 \\
6 \cdot 5 \\
11 \cdot 5 \\
10 \cdot 2 \\
18 \cdot 6 \\
23 \cdot 6\end{array}$ \\
\hline
\end{tabular}

ringer Mannheim, West Germany) at a final concentration of $1 \mu \mathrm{g} / \mathrm{ml}$ in the presence of $0.2 \%$ Triton-X100.

PREPARATION OF CELL SUSPENSIONS OBTAINED FROM PARAFFIN EMBEDDED MATERIAL

This method is based on that described by Hedley et $a^{6}{ }^{6}$ with only a few modifications. Briefly, $30 \mu \mathrm{m}$ paraffin sections were dewaxed in xylene and rehydrated through a series of alcohols $(100 \%, 95 \%$, $70 \%$, and $50 \%$ ) into distilled water. The sections were then treated for 30 minutes at $37^{\circ} \mathrm{C}$ in a 5 $\mathrm{mg} / \mathrm{ml}$ solution of pepsin (Sigma, Dorset, England) at $\mathrm{pH} 1 \cdot 5$. The resulting suspension was spun at $2000 \mathrm{rpm}$ for three minutes and resuspended in $5 \mathrm{ml}$ of Isoton (Coulter Electronics, Luton, England) containing $1 \mu \mathrm{g} / \mathrm{ml}$ DAPI. As will be discussed below, for most studies the suspensions were passed through a 25 gauge needle before filtration through $35 \mu \mathrm{m}$ pore nylon gauze.

\section{FLOW CYTOMETRY}

Samples were analysed with a Becton Dickinson (California, United States of America) FACS analyser powered by a mercury arc lamp. The fluorochrome was excited in the ultraviolet (peak wave-

Table 2 DNA indices of fresh and paraffin embedded samples of non-Hodgkin's lymphoma

\begin{tabular}{|c|c|c|c|c|}
\hline \multirow[t]{3}{*}{ Case No } & \multicolumn{4}{|c|}{ DNA ploidy } \\
\hline & \multicolumn{2}{|c|}{ Fresh } & \multicolumn{2}{|c|}{ Fixed } \\
\hline & $C V$ & DNA index & $C V$ & $D N A$ index \\
\hline $\begin{array}{l}1 \\
2 \\
3 \\
4 \\
5 \\
6 \\
7 \\
8 \\
9 \\
\text { Mean }\end{array}$ & $\begin{array}{l}6 \cdot 9 \\
5 \cdot 0 \\
3 \cdot 0 \\
4 \cdot 1 \\
4 \cdot 2 \\
5 \cdot 4 \\
2 \cdot 6 \\
4 \cdot 9 \\
4 \cdot 2 \\
4 \cdot 5\end{array}$ & $\begin{array}{l}1.0 \\
1.0 \\
1.0 \\
1.0 \\
1.0 \\
1.0 \\
1.0 \\
1.0 \\
1.0\end{array}$ & $\begin{array}{l}4 \cdot 1 \\
3 \cdot 3 \\
4 \cdot 2 \\
4 \cdot 1 \\
3 \cdot 8 \\
5 \cdot 8 \\
3 \cdot 4 \\
2 \cdot 8 \\
5 \cdot 8 \\
4 \cdot 1\end{array}$ & $\begin{array}{l}1 \cdot 0 \\
1.0 \\
1 \cdot 0 \\
1.0 \\
1 \cdot 0 \\
1.0 \\
1 \cdot 8 \\
1 \cdot 0 \\
1 \cdot 0\end{array}$ \\
\hline
\end{tabular}

$\mathrm{CV}=$ coefficient of variation. length $360 \mathrm{~nm}$ ), and fluorescence in the blue region of the spectrum (peak $490 \mathrm{~nm}$ ) was collected. To construct each DNA histogram 10 000-15 000 cells were scanned and the data stored on disc for subsequent analyses. The DNA index - that is, the position of any aneuploid peaks relative to the normal $\mathrm{G}_{\mathrm{I}}$ peak-was determined; a DNA index of 1.0 indicates the presence of diploid cells alone. In addition, the percentage of cells with $S$ phase DNA contents was calculated by the method of Baisch et al. ${ }^{7}$

\section{Results}

Early in this study we realised that cell suspensions from paraffin sections had a variable amount of residual clumping. To remove these clumps the cell suspensions were passed through a small gauge needle. In addition to removing aggregates of whole cells this procedure had an effect on the calculated $\mathrm{S}$ phase fractions (Table 1). Initially, we had noted that estimates of $S$ phase fraction from paraffin embedded material were consistently and significantly higher than those estimated from fresh tissue samples. After needling, however, $S$ phase estimates from paraffin material became similar to those from fresh tissue samples and were no longer significantly different from them (paired $t$ test). Subsequently, suspensions were needled routinely.

The quality of results obtained from the paraffin material compared favourably with that from fresh tissue samples as judged by the coefficient of variation of the $G_{I}$ peaks (Table 2). The figure gives a comparison of histograms from fresh and paraffin material from the same lymph node (case 7). Clearly, there was good agreement between the two histograms. Table 2 also gives the DNA indices calculated from fresh and paraffin material. Five tumours were classified as low grade non-Hodgkin's lymphoma (cases 1-5). Apart from case 5, these tumours had low $S$ phase fractions, and all were diploid. Four tumours (cases 6-9) were high grade 

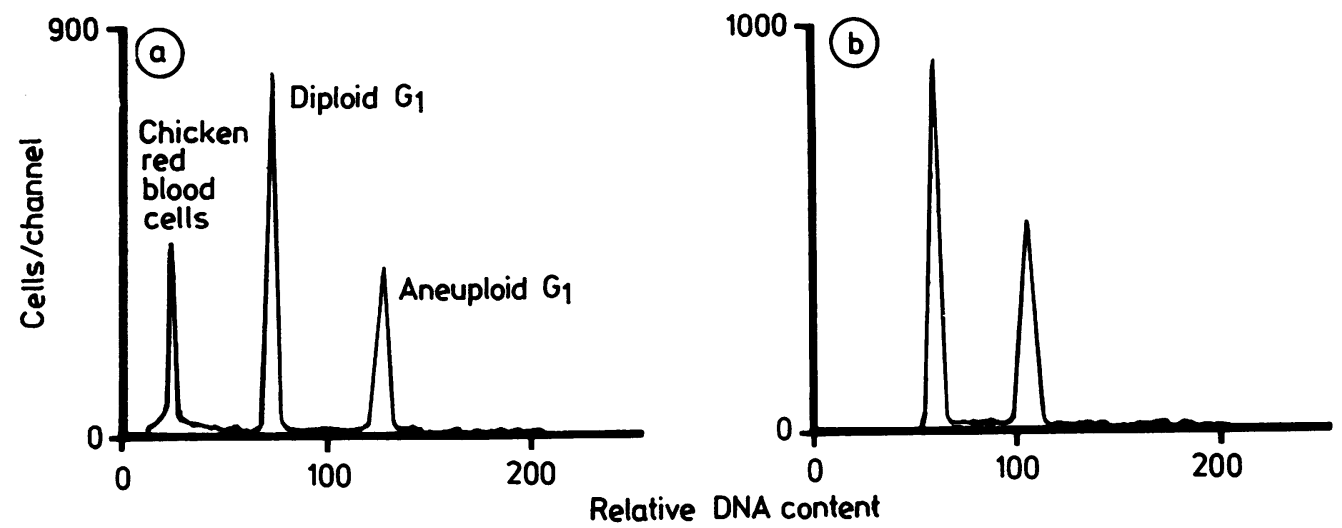

Fig. 1 (A) DNA histogram from fresh tissue from case 7 (Tables 1 and 2). Chicken red blood cells were added as an internal DNA standard and the machine adjusted to give the peak of their fuorescence in channel 25. Distinct diploid and aneuploid (DI 1.8) peaks of lymphoma cells can be seen. (B) DNA histogram from paraffin tissue from case 7. Peak fuorescence for the diploid $G_{I} \mid$ cells is set in channel 60 . Once again a distinct aneuploid peak is seen (DI 1.8).

non-Hodgkin's lymphoma and had higher $\mathrm{S}$ phase fractions, although only case 7 had an aneuploid DNA content (Figure). In this case a clear aneuploid population of cells was seen in both fresh and fixed samples. In none of the nine cases was there any difference in DNA index for samples prepared by the two methods.

\section{Discussion}

The preliminary results obtained from the fixed material agree with earlier published data on nonHodgkin's lymphoma ${ }^{2-5}$ in that higher grade lymphomas tend more often to be aneuploid and have higher $\mathrm{S}$ phase fractions. The incidence of aneuploidy in this study, however, is lower than other published estimates. In this study only one out of nine cases contained a second $\mathrm{G}_{\mathrm{I}}$ peak of cells. Published estimates for the occurrence of aneuploidy in nonHodgkin's lymphoma are much higher.' One limitation of DNA flow cytometry from paraffin material is the inability to use either chicken red blood cells or human peripheral blood lymphocytes as DNA standards for calibration. Thus in principle it would not be possible to recognise aneuploid cells without some concomitant diploid cells in the sample under study. Our experience, however, with a wide range of tumour samples supports that of Hedley et $\mathrm{al}^{6}$ in that some diploid cells have invariably been present in all samples analysed from fresh tis\$ue. Thus aneuploid cells can be recognised by the presence of a separate second $\mathrm{G}_{\mathrm{I}}$ peak (Figure).

In our opinion, therefore, the low incidence of aneuploidy in this small series is most probably due to the effects of patient selection rather than false negative results. This interpretation is supported by the fact that aneuploidy was more common in a much larger and more representative series of non-Hodgkin's lymphoma (unpublished data).

The apparent reduction in calculated $S$ phase frac $\Omega$ tions (Table 1) seen after needling cell suspensions may have a simple explanation. We have shown that this procedure reduces the incidence of clumps of whole cells. When suspensions are prepared from thick sections of tissue, however, there will be fragments of cells (from the cut surfaces) as well as whole cells. It may be that using a needle also breaks up clumps composed of mixtures of whole and part cells; such clumps may have intermediate DNA values falling in the $S$ phase region. These would increase the calculated $S$ phase fraction artefactually, and their removal would give a more accurate assessment of the true $S$ phase fraction.

In general, we think that DNA flow cytometry of suspensions from paraffin embedded samples of non-Hodgkin's lymphoma gives a reliable and accurate assessment of both DNA index (aneuploidy) and $S$ phase fraction. We are using this technique to investigate a much larger series of non-Hodgkin's lymphoma and other tumours.

We thank Mr MG Stone, Mrs J Alder, and Miss G Powell for their expert technical help.

\footnotetext{
References

' Barlogie B, Raber MN, Schumann J, et al. Flow cytometry in clinical cancer research. Cancer Res 1983;43:3982-7.

${ }^{2}$ Friedlander ML, Hedley DW, Taylor IW. Clinical and biological significance of aneuploidy in human tumours. J. Clin Pathol 1984;37:961-74.
} 
${ }^{3}$ Braylan RC, Foulkes BJ, Jaffe ES, Sanders SK, Berard CW, Herman CJ. Cell volumes and DNA distributions of normal and neoplastic human lymphoid cells. Cancer 1978;41:201-9.

4 Diamond LW, Braylan RC. Flow analysis of DNA content and cell size in non-Hodgkin's lymphoma. Cancer Res 1980;40:703-12.

5 Diamond LW, Nathwani BN, Rappaport H. Flow cytometry in the diagnosis and classification of malignant lymphoma and leukaemia. Cancer 1982;50:1122-35.

- Hedley DW, Friedlander ML, Taylor IW, Rugg CA, Musgrove EA. Method for analysis of cellular DNA content of paraffin- embedded pathological material using flow cytometry. J Histochem Cytochem 1983;31:1333-5.

' Baisch H, Gohde W, Linden WA. Analysis of PCP-data to determine the fraction of cells in the various phases of cell cycle. Radiat Environ Biophys 1975; 12:31-9.

Requests for reprints to: Dr JC Macartney, Department of Histopathology, North Wing, St Thomas's Hospital, London SE1 7EH, England. 